\title{
Toward a Conceptual Model for Examining the Role of Social Media on Social Customer Relationship Management (SCRM) System
}

\author{
Abdullah M. Baabdullah ${ }^{1}$, Nripendra P Rana², Ali Abdallah Alalwan ${ }^{3}$, Raed \\ Algharabat $^{4}$, Hatice Kizgin ${ }^{5}$, and Ghazi A. Al-Weshah ${ }^{6}$ \\ ${ }^{1}$ Department of Management Information Systems, Faculty of Economics and Administration, \\ King Abdulaziz University, Jeddah, Kingdom of Saudi Arabia \\ baabdullah@kau.edu.sa \\ ${ }^{2}$ School of Management, Swansea University, Bay Campus, Fabian Way, Swansea SA1 8EN, \\ UK \\ nrananp@gmail.com \\ ${ }^{3}$ Amman College of Banking and Finance, Al-Balqa Applied University, Amman, Jordan \\ alwan.a.a.ali@gmail.com \\ Alwan_jo@bau.edu.jo \\ ${ }^{4}$ The School of Business Department of Marketing, The University of Jordan, Amman, Jordan \\ r.gharabat@ju.edu.jo \\ ${ }^{5}$ School of Management, Swansea University, Bay Campus, Fabian Way, Swansea SA1 8EN, \\ UK \\ hatice.kizgin@swansea.ac.uk \\ ${ }^{6}$ Faculty of Business Al-Balqa Applied University, Salt, Jordan \\ weshah120@yahoo.com
}

\begin{abstract}
Organizations worldwide are becoming more interested in utilizing social media applications to enhance their marketing capabilities. One of the main fruits of integrating social media applications into the marketing, information technology and information systems areas is social customer relationship management (SCRM). SCRM has been the focus of attention for both marketing academics and practitioners. However, as this area is quite new, there is a need to propose a theoretical foundation explaining how using social media platforms for SCRM systems could predict customer engagement and customer relationship performance. Three main factors, i.e. social media use, a customer-centric management system, and relationship marketing orientation, are considered as key predictors of SCRM. SCRM is proposed as a key determinant of customer engagement, which in turn affects customer relationship performance. The proposed research methodology suggests conducting a quantitative study to validate the current study model. Further discussion regarding the research contribution and main limitations are provided in the last sections.
\end{abstract}

Keywords: SCRM, Social Media, Customer Engagement, Jordan 


\section{Introduction}

Recently, organizations worldwide seem to have become more interested in utilizing different information technology and digital marketing tools to sustain their relationships with their customers as well as to maintain their market share $[5,9,11$, 27, 37]. Web 2.0 and social media applications (i.e. Facebook, Twitter, Instagram, YouTube, and Snapchat) therefore have been the focus of attention for modern organizations [4]. This is due to the innovative nature of such applications, which attract millions of customers and allow a high degree of interactivity either between customers themselves or between customers and organizations. Noticeably, customer relationship management (CRM) systems are progressively considering social media platforms as new mechanisms to conduct their activities [30]. A CRM system is one of the most important enterprise systems in addition to supply chain management (SCM) and enterprise resource planning (ERP).

As a result of integrating social media applications into the area of CRM systems, a new trend called social CRM (SCRM) has evolved [5]. Conceptually, SCRM was defined by [31, p. 319] as "the integration of customer-facing activities, including processes, systems, and technologies, with emergent social media applications to engage customers in collaborative conversations and enhance customer relationships" [31, p. 319]. In fact, SCRM could not exist without such revaluation of expanding the uses of social media and Web 2.0 applications over the CRM area [14]. Such integration has emerged with the intention of providing firms and companies with more capabilities to contribute to customer satisfaction and experience $[1,4,28,30]$. SCRM also expands the horizon of CRM activities with a sufficient level of customer participation and engagement, which, in turn, significantly reflects on the overall marketing performance [21, 22, 29, 37].

However, there is always a critical question regarding the feasibility and applicability of using social media tools for SCRM activities [3]. This calls for further examination and explanation of the related issues of SCRM and its feasibility and applicability as a new system considered by marketers [4, 30]. More importantly, there are a limited number of studies that have tested how using social media platforms for SCRM systems could add value to organization performance [3]. As this area is quite new, the current study realizes the necessity of proposing a theoretical foundation which could provide a clear picture explaining how using social media platforms for SCRM systems could predict customer performance.

\section{$2 \quad$ Literature Review}

SCRM issues have been the focus of a number of recent studies (i.e. [5, 15, 26, 30, 41]. Some of these studies (i.e. $[15,13,23,36])$ reported that SCRM could contribute many values and utilities for marketers. For example, marketers are currently more able to efficiently produce a large amount of data with a certain degree of customization, interactivity, and informativeness [6]. Further, due to the interactive nature of Web 2.0 applications that empowers customers to actively communicate and 
interact with other customers and organizations, there are more opportunities to build online community and strong brands [24]. This, in turn, leads to more customer involvement and engagement [30]. In this regard, customers are more active and engaged with marketing activities conducted in social media such as creating their own content, publishing their experience, encouraging other customers, and so on [4, 30]. In the light of such advantages of SCRM, a large amount of time, effort, and money has been projected in the area of SCRM systems [28].

However, [5] argued that if the adoption of SCRM systems is very low, organizations would not be able to reach the related values of SCRM effectively. [10] recently assured the importance of the contribution of SCRM to the marketing services activities in the hotel context such as enhancing customer associations, customer performance, and financial performance. [32] emphasized the role of social media tools in the area of SCRM via enhancing the role of value co-creation as well as arguing how the integrated mechanism of SCRM could be accelerated by engaging the social capabilities that are available in the social media platforms, which, in turn, reflects in both financial and non-financial performance. As reported by [3], modern organizations are looking forward to applying SCRM systems to have an effective means of contact with their customers as well as to sustain their associations with them. This is in addition to the ability of SCRM to facilitate accessing the big data available in social media platforms about customers.

Even though these studies have attempted to examine either the adoption of SCRM or the impact of SCRM systems, there is still a need to clarify the main dimensions of SCRM over the social media platforms and how such dimensions could contribute to financial and customer performance. Therefore, this study attempts to fill this gap by proposing a conceptual model which could cover the fundamental aspects of SCRM over the social media area.

\section{Conceptual Model and Research Hypotheses}

Based on a critical review of the main models and studies (i.e. [8, 15, 16, 18, 19, 32]) that have tested SCRM, this study formulates the current model presented in Figure 1. In detail, a Capabilities-Based Perspective was considered in the current study as a theoretical foundation [31]. As seen in Figure 1, the most important antecedences and consequences are considered in one single model. As this study considers the implementation of SCRM over the social media platforms, it was important to consider the impact of social media on SCRM. Indeed, this impact of social media has been addressed by [16, 30, 32]. Relationship marketing orientation was argued by [16] as an important requirement for SCRM. [2, 31] approved the critical role of customer-centric management. It was also important that the impact of SCRM on customer engagement has been validated by different studies such as $[15,16,30]$. Finally, customer relationship performance (financial and non-financial) was proposed to be the main consequences of SCRM and engagement. Accordingly, this study proposes the following research hypotheses: 
H1: Social media use will positively influence SCRM capabilities.

H2: A customer-centric management system will positively influence SCRM capabilities.

H3: Relationship marketing orientation will positively influence SCRM capabilities. H4: SCRM capabilities will positively influence customer engagement.

H5: Customer engagement will positively influence customer relationship performance.

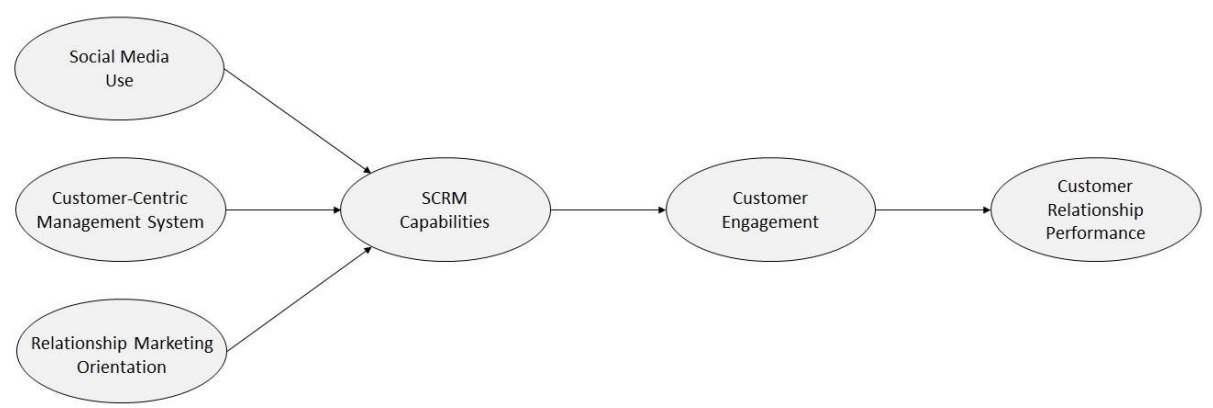

Figure 1. Conceptual Model (Adapted from $[8,15,16,18,32])$

It is also worth indicating that SCRM is addressed as a multidimensional construct in the current study. This is in line with what has been proposed and supported $[17,18$, 32]. These dimensions are presented in Figure 2. By the same token, three main dimensions, i.e. behavioural, cognitive, and emotional, are all adapted to reflect customer engagement. (See Figure 3. These aspects of customer engagement were adopted from [15]).

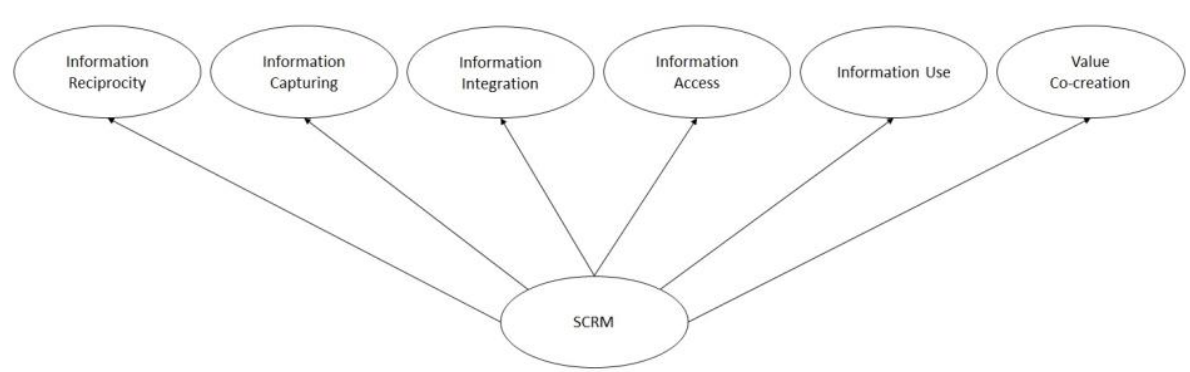

Figure 2. SCRM Capabilities (Adapted from $[17,18,32]$ ) 


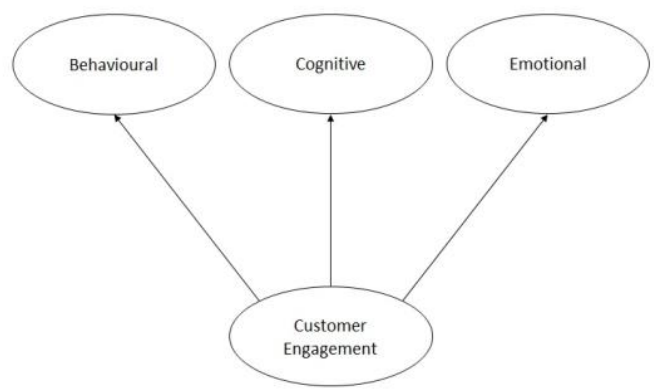

Figure 3. Customer Engagement Dimensions (Adapted from $[15,16])$

\section{$4 \quad$ Proposed Research Methodology}

As discussed above, the current study model and research hypotheses has been proposed based on what has been tested and supported in prior studies. Thus, the nature of this study seems to be more positivist deductive, and accordingly, the quantitative method has been adopted to capture adequate statistical evidences $[7,12$, 25]. The targeted context of this study will be different firms from the service context in Jordan: mobile communication firms, banks, and travel and tourism agencies in Jordan. This is due to the fact that these firms have extensively adopted and apply social media tools for SCRM activities. Moreover, these organizations have their place in different social media platforms (Facebook, Instagram, Twitter, and YouTube) along with the fact that millions of customers follow these firms on social media platforms. In detail, a field survey questionnaire will be allocated to marketing managers, staff in the marketing department, social media managers, and admins at these organizations. Factors will be measured using scale items adapted from previous studies. For instance, the main aspects of SCRM, i.e. information reciprocity, information capturing, information integration, value co-creation, and information use, will be adapted from [18]. These items have also been validated and tested by $[28,32,38,39,40]$. Items from $[16,18,33]$ will be adapted to test the customer relationship orientation construct. The customer-centric management system will be tested using scale items from [28]. The scale adapted from [15, 16, 36] will be considered to evaluate customer engagement. Once the data has been collected, it will be processed using structural equation modeling analyses to validate the conceptual model and research hypotheses.

\section{$5 \quad$ Research Contribution}

Even though there is considerable interest in the applications of social media tools for marketing aims, there is still a strong need to explain and examine how SCRM could be accelerated by such applications. This is in addition to the fact that a comprehensive theoretical model is much needed to see which aspects in SCRM systems could be affected by social media use. This model should also clarify how SCRM activities in social media could contribute to customer engagement and customer relationship performance. Therefore, this study would hopefully provide 
further understanding regarding the related issues of SCRM over the social media platforms especially in the light of the limited number of studies that have tested SCRM over the social media platforms. Further, the targeted context of this study as mentioned in the proposed research methodology is different service organizations in Jordan. Indeed, such issues have yet to be examined in Jordan or even in the Arab countries. This in turn confirms the importance of conducting this study. While the prior SCRM studies have considered an individual context like banking, i.e. [34, 38]; tourism, i.e. [34]; and hotels, i.e. [35], this study considers different kinds of organizations over the service context. Thus, rich results could be attained once this model has been empirically tested which could provide more clues to help firms in how they can effectively apply SCRM activities over the social media area.

\section{$6 \quad$ Limitations and Future Research Directions}

In spite of the considerable contribution that could be attained in the current study, there is a number of limitations that really restrict this study. For example, this study is more conceptual and theoretical, and it has not been tested yet. Therefore, there is a need to collect adequate statistical evidences by collecting data from the targeted organizations who are interested in SCRM activities in social media. The current study model was built based on what has been discussed and approved over the prior literature. This could affect the applicability of the current model over the Jordanian context especially in the fact that most of the prior studies have been conducted in the developed countries. Therefore, conducting an exploratory study using a number of interviews with those who are experts in CRM and social media marketing could be more useful.

\section{References}

1. Abed, S. S., Dwivedi, Y. K., \& Williams, M. D.: Social media as a bridge to ecommerce adoption in SMEs: A systematic literature review. The Marketing Review, 15(1), 39-57 (2015).

2. Abeza, G., O'Reilly, N., \& Reid, I.: Relationship marketing and social media in sport. International Journal of Sport Communication, 6(2), 120-142 (2013).

3. Ahani, A., Rahim, N. Z. A., \& Nilashi, M.: Forecasting social CRM adoption in SMEs: A combined SEM-neural network method. Computers in Human Behavior, 75, 560-578 (2017).

4. Alalwan, A. A., Rana, N. P., Dwivedi, Y. K., \& Algharabat, R.: Social media in marketing: A review and analysis of the existing literature. Telematics and Informatics (2017).

5. Askool, S., \& Nakata, K.: A conceptual model for acceptance of social CRM systems based on a scoping study. Ai \& Society, 26(3), 205-220 (2011).

6. Berthon, P. R., Pitt, L. F., Plangger, K., \& Shapiro, D.: Marketing meets Web 2.0, social media, and creative consumers: Implications for international marketing strategy. Business horizons, 55(3), 261-271 (2012).

7. Bhattacherjee, A.: Social science research: Principles, methods, and practices (2012).

8. Choudhury, M. M., \& Harrigan, P.: CRM to social CRM: the integration of new technologies into customer relationship management. Journal of Strategic Marketing, 22(2), 149-176 (2014). 
9. Coulter, K. S., \& Roggeveen, A.: "Like it or not" Consumer responses to word-ofmouth communication in on-line social networks. Management Research Review, 35(9), 878-899 (2012).

10. Diffley, S., McCole, P., \& Carvajal-Trujillo, E.: Examining social customer relationship management among Irish hotels. International Journal of Contemporary Hospitality Management, (just-accepted), 00-00 (2018).

11. Dwivedi, Y. K., Rana, N. P., Tajvidi, M., Lal, B., Sahu, G. P., \& Gupta, A.: Exploring the Role of Social Media in e-Government: an Analysis of Emerging Literature. In Proceedings of the 10th International Conference on Theory and Practice of Electronic Governance (pp. 97-106). ACM (2017, March).

12. Dwivedi, Y., and Irani, Z.: Understanding the adopters and non-adopters of broadband. Communications of the ACM, 52(1), 122-125 (2009).

13. Hajli, N., Shanmugam, M., Papagiannidis, S., Zahay, D., \& Richard, M. O.: Branding co-creation with members of online brand communities. Journal of Business Research, 70, 136-144 (2017).

14. Harrigan, P., \& Miles, M.: From e-CRM to s-CRM. Critical factors underpinning the social CRM activities of SMEs. Small Enterprise Research, 21(1), 99-116 (2014).

15. Harrigan, P., Evers, U., Miles, M., \& Daly, T.: Customer engagement with tourism social media brands. Tourism Management, 59, 597-609 (2017).

16. Harrigan, P., Soutar, G., Choudhury, M. M., \& Lowe, M.: Modelling CRM in a social media age. Australasian Marketing Journal (AMJ), 23(1), 27-37 (2015).

17. Jaakkola, E., Helkkula, A., \& Aarikka-Stenroos, L.: Service experience co-creation: conceptualization, implications, and future research directions. Journal of Service Management, 26(2), 182-205 (2015).

18. Jayachandran, S., Sharma, S., Kaufman, P., \& Raman, P.: The role of relational information processes and technology use in customer relationship management. Journal of marketing, 69(4), 177-192 (2005).

19. Kapoor, K. K., Tamilmani, K., Rana, N. P., Patil, P., Dwivedi, Y. K., and Nerur, S.: Advances in Social Media Research: Past, Present and Future. Information Systems Frontiers, 20(3), 531-558 (2018).

20. Kline, R. B.: Principles and Practice of Structural Equation Modelling. New York: The Guilford Press (2005).

21. Leeflang, P. S., Verhoef, P. C., Dahlström, P., \& Freundt, T.: Challenges and solutions for marketing in a digital era. European management journal, 32(1), 1-12 (2014).

22. Leung, X. Y., Bai, B., \& Stahura, K. A.: The marketing effectiveness of social media in the hotel industry: A comparison of Facebook and Twitter. Journal of Hospitality \& Tourism Research, 39(2), 147-169 (2015).

23. McCarthy, J., Rowley, J., Jane Ashworth, C., \& Pioch, E.: Managing brand presence through social media: the case of UK football clubs. Internet Research, 24(2), 181204 (2014).

24. McCole, D.: Seasonal employees: The link between sense of community and retention. Journal of Travel Research, 54(2), 193-205 (2015).

25. Orlikowski, W. J., \& Baroudi, J. J.: Studying information technology in organizations: Research approaches and assumptions. Information systems research, 2(1), 1-28 (1991).

26. Shareef, M. A., Mukerji, B., Dwivedi, Y. K., Rana, N. P., and Islam, R.: Social media marketing: Comparative effect of advertisement sources. Journal of Retailing and Consumer Services (2017). DoI: https://doi.org/10.1016/j.jretconser.2017.11.001

27. Starkey Lewis, P. J., Dear, J., Platt, V., Simpson, K. J., Craig, D. G., Antoine, D. J., ... \& Neoptolemos, J. P.: Circulating microRNAs as potential markers of human drug-induced liver injury. Hepatology, 54(5), 1767-1776 (2011). 
28. Trainor, K. J., Andzulis, J. M., Rapp, A., \& Agnihotri, R.: Social media technology usage and customer relationship performance: A capabilities-based examination of social CRM. Journal of Business Research, 67(6), 1201-1208 (2014).

29. Tuten, T., \& Solomon, M.: Social media marketing. 2. painos. Great Britain: Sage Publication (2015)

30. Wang, Z., \& Kim, H. G.: Can social media marketing improve customer relationship capabilities and firm performance? Dynamic capability perspective. Journal of Interactive Marketing, 39, 15-26 (2017).

31. Trainor, K. J.: Relating social media technologies to performance: A capabilitiesbased perspective. Journal of Personal Selling and Sales Management, 32(3), 317$331(2012)$.

32. Diffley, S., \& McCole, P.: Extending customer relationship management into a social context. The Service Industries Journal, 35(11-12), 591-610 (2015).

33. Sin, L. Y. M., Tse, A. C. B., \& Yim, F. H. K.: CRM: Conceptualization and scale development. European Journal of Marketing, 39(11-12), 1264-1290 (2005).

34. Giannakis-Bompolis, C., \& Boutsouki, C.: Customer relationship management in the era of social web and social customer: an investigation of customer engagement in the Greek retail banking sector. Procedia-Social and Behavioral Sciences, 148, 67-78 (2014).

35. Alalwan, A. A., Dwivedi, Y. K., Rana, N. P., \& Williams, M. D.: Consumer adoption of mobile banking in Jordan: examining the role of usefulness, ease of use, perceived risk and self-efficacy. Journal of Enterprise Information Management, 29(1), 118-139 (2016).

36. Algharabat, R., Alalwan, A. A., Rana, N. P., \& Dwivedi, Y. K.: Three dimensional product presentation quality antecedents and their consequences for online retailers: The moderating role of virtual product experience. Journal of Retailing and Consumer Services, 36, 203-217 (2017).

37. Algharabat, R., Rana, N. P., Dwivedi, Y. K., Alalwan, A. A., \& Qasem, Z: The effect of telepresence, social presence and involvement on consumer brand engagement: An empirical study of non-profit organizations. Journal of Retailing and Consumer Services, 40, 139-149 (2018).

38. Alalwan, A. A., Dwivedi, Y. K., Rana, N. P., \& Algharabat, R.: Examining factors influencing Jordanian customers' intentions and adoption of internet banking: Extending UTAUT2 with risk. Journal of Retailing and Consumer Services, 40, 125138 (2018).

39. Dwivedi, Y. K., Rana, N. P., Janssen, M., Lal, B., Williams, M. D., \& Clement, M.: An empirical validation of a unified model of electronic government adoption (UMEGA). Government Information Quarterly, 34(2), 211-230 (2017).

40. Dwivedi, Y. K., Rana, N. P., Jeyaraj, A., Clement, M., \& Williams, M. D.: Reexamining the Unified Theory of Acceptance and Use of Technology (UTAUT): Towards a Revised Theoretical Model. Information Systems Frontiers, (2017). DoI: https://doi.org/10.1007/s10796-017-9774-y

41. Shareef, M. A., Mukerji, B., Alryalat, M. A. A., Wright, A., \& Dwivedi, Y. K.: Advertisements on Facebook: Identifying the persuasive elements in the development of positive attitudes in consumers. Journal of Retailing and Consumer Services, 43, 258-268 (2018). DoI: https://doi.org/10.1016/j.jretconser.2018.04.006 